\title{
Tại sao biến thể Delta của virus SARS- CoV-2 lại lan nhanh?
}

\author{
- sciencevietnam $F$ SciComm (1) July 27,2021
}

ENHANCED BY Google

SSHPA (27-07-2021) — Một nghiên cứu mới thực hiện tại Trung Quốc cho thấy những người nhiễm biến thể Delta có tải lượng virus cao gấp khoảng 1000 lần so với những người nhiễm loại SARS-CoV-2 gốc.

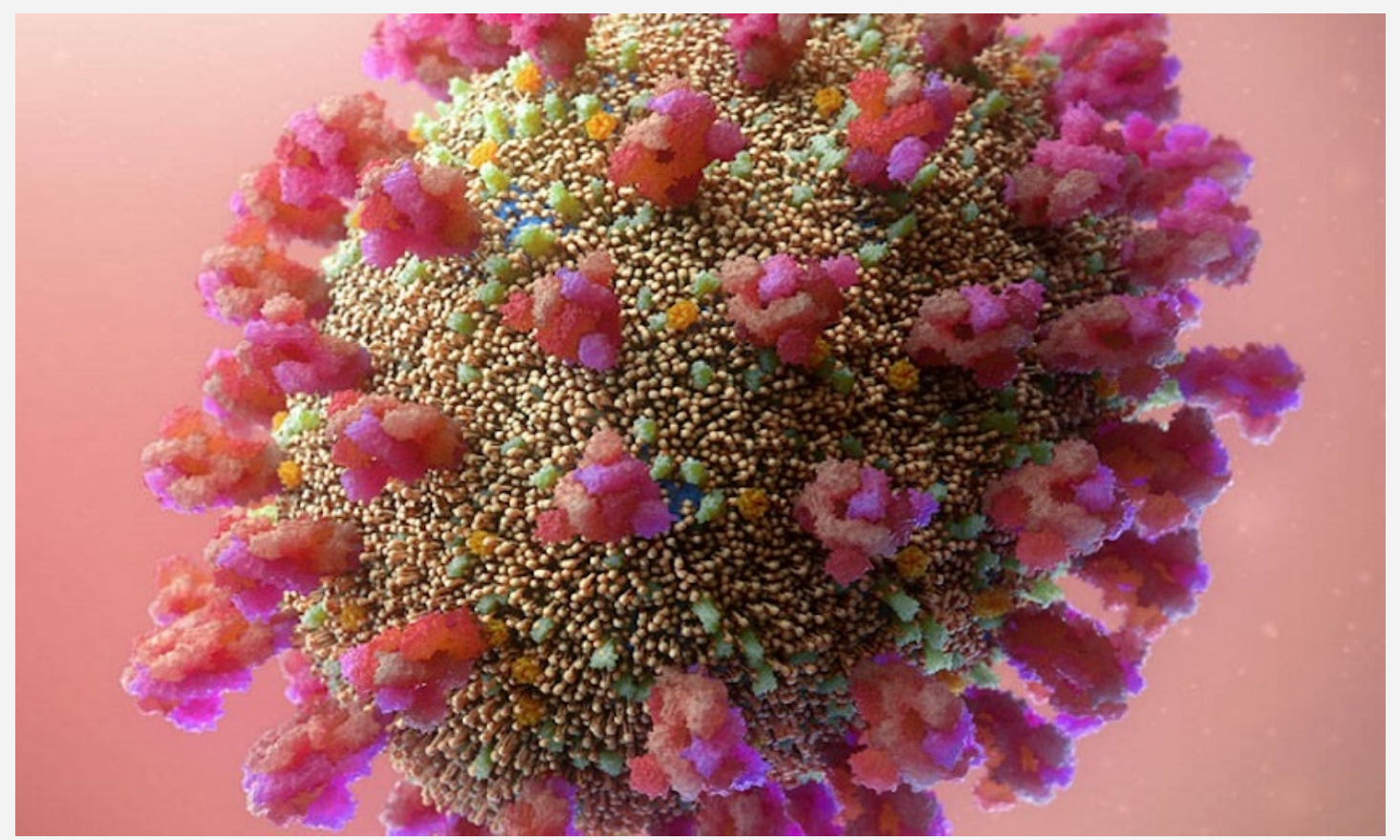

Biến thể Delta xuất hiện lần đầu tiên tại Ấn Độ vào cuối năm 2020, nhanh chóng lan ra và trở thành nguyên nhân lây nhiễm phổ biến khắp nơi trên thế giới. Tính toán hiện nay cho thấy tốc độ lây lan của biến thể Delta cao gấp hai lần so với loại gốc.

Để tìm hiểu nguồn cơ lây nhiễm nhanh, một nhóm nghiên cứu dẫn đầu bởi nhà dịch tế học Jing Lu (Trung tâm Kiểm soát và Phòng ngừa Bệnh tỉnh Quảng Đông, tại Quảng Châu, Trung Quốc) đã thực hiện đo và so sánh tải lượng virus giữa nhóm nhiễm thể Delta và thể gốc vào năm 2020 [1].

Nghiên cứu được xuất bản dưới dạng preprint trên medRxiv vào ngày 12 tháng 7 và được tạp chí Nature đưa tin vào 9 ngày sau [2]. Báo cáo cho thấy người nhiễm biến thể Delta có thể được phát hiện sau 4 ngày kể từ khi tiếp xúc, trong khi người nhiễm thể gốc mất trung bình khoảng 6 ngày. Ngoài ra, kết quả cho thấy người nhiễm biến thể Delta có tải lượng virus cao gấp 1260 lần so với người nhiễm thể cũ.

Sự kết hợp giữa thời gian ủ bệnh ngắn và tải lượng cao có thể là nguyên nhân giải thích tốc độ lây lan nhanh của biến thể Delta. Dù chưa rõ tại sao biến thể Delta lại nguy hiểm hơn thể gốc và liệu biến thể này có thể dễ dàng xâm nhập hệ miễn dịch ra sao, các nhà nghiên cứu gợi ý rằng nên nghiên cứu biến thể này với nhiều nhóm 
người nhiễm khác nhau, thúc đẩy quá trình tìm kiếm thông tin. Trong lúc cam go chiến đấu với dịch bệnh, chia sẻ dữ liệu mở và thông tin mở trở nên vô cùng quan trọng, giúp thúc đẩy quá trình nghiên cứu chống lại dịch bệnh $[3,4]$.

\section{Tài liệu tham khảo:}

[1] Li B, et al. (2021). Viral infection and transmission in a large, well-traced outbreak caused by the SARS-CoV-2 Delta variant. medRxiv, https://doi.org/10.1101 /2021.07.07.21260122

[2] Reardon, S. (2021). How the Delta variant achieves its ultrafast spread. Nature, doi: https://doi.org/10.1038/d41586-021-01986-w

[3] Vuong QH, et al. (2021). Covid-19 vaccines production and societal immunization under the Serendipity-Mindsponge-3D knowledge management theory and conceptual framework. SocArXiv, doi:10.31235/osf.io/4mchu.

[4] Vuong QH. (2017). Open data, open review and open dialogue in making social sciences plausible. Nature: Scientific Data Updates. URL: http://blogs.nature.com /scientificdata/2017/12/12/authors-corner-open-data-open-review-and-opendialogue-in-making-social-sciences-plausible/

\section{(1) Last modified: $7 / 28 / 20213: 30$ PM
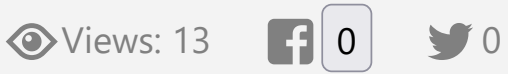

\section{Bài liên quan:}

- UKRI công bố chính sách xuất bản mơ

- Voọc chà vá chân nâu - Một trong những loài khỉ đẹp nhất thế giới

- Hiệu quả của các vaccine phòng COVID-19 trước biến thể Delta (B.1.167.2)

- Vaccine Sputnik của Nga cho thấy hiệu quả

- Quỹ Vaccine phòng chống Covid-19: Một mốc lịch sử kinh tế đương đại

\section{Ý kiến bạn đọc (0):}

Comment

Gửi bình luận

(C) 2018 - 2021 EASE Vietnam SciComm System. All rights reserved. Powered by Vuong \& Associates. Built to serve the social sciences and humanities. 